\title{
Quantitative Analysis on the Evaluation Indicators of Teaching Abilities of Physical Education Teachers in Colleges and Universities
}

\author{
https://doi.org/10.3991/ijet.v16i18.25661 \\ Xinjun Luo \\ Guizhou University of Commerce, Guiyang, China \\ clown01esina.com
}

\begin{abstract}
This paper studies the teaching abilities of physical education (P.E.) teachers in colleges and universities. First, an evaluation indicator system for the teaching abilities of P.E. teachers in colleges and universities was constructed using the Delphi method, and then the weights of indicators at each level were determined using the expert survey method, so that a standard scale was formed for the teaching ability evaluation system. After that, empirical analysis was performed on the evaluation indicator system. The research results show that the teaching ability evaluation indicator system for P.E. teachers in colleges and universities proposed in this paper can be used to give a quantitative analysis on teachers' teaching abilities and clearly reflect their deficiencies in teaching. This will allow teachers to understand what to improve in their teaching so that their teaching abilities will be enhanced. This research provides theoretical and practical references for the evaluation of P.E. teachers' teaching abilities in higher education institutions in China, and thus, it is of great theoretical and practical significance to promoting the reform of P.E. teaching in higher education and the professional development of teachers.
\end{abstract}

Keywords — colleges and universities, P.E. major, teaching ability, evaluation indicator, Delphi method, quantitative analysis.

\section{Introduction}

Building China into a sports power is the goal and task of the sports reform and development in China in the new era. In this background, the quality of physical education has received widespread attention. Sports majors in colleges and universities are set up to cultivate professional sports talents. To accomplish this mission, P.E. teachers play an essential part, as they are the main implementers of physical education and teaching. Their teaching abilities have vital influences on the quality and effect of physical education [1]. To improve the teaching quality of physical education and cultivate excellent professional sports talents, it is truly necessary to evaluate the teaching abilities of P.E. teachers in colleges and universities.

Talents are the primary force driving the development of the society. Having recognizing this, countries all over the world are paying more and more attention to tal- 
ent cultivation, and accordingly, governments and the society have also put forward higher requirements for the teaching level and quality of education institutions [2]. Considering that the teaching abilities of teachers are the key factor to improving the teaching quality, more and more experts and scholars have carried out research on teaching abilities and the evaluation thereof [3]. At present, the research on teaching abilities of teachers at home and abroad is carried out mainly on the classification of teaching abilities. Since different scholars have different focuses, there has been no clear standard [4]. For example, some scholars studied the teaching organization, management and classroom design abilities of teachers [5], and some proposed structural classification of teachers' abilities, like sports research, innovation and action demonstration abilities [6]. In some foreign countries, the research on the teaching ability evaluation system for teachers started quite early and has received high attention. The teaching evaluation on teachers in Japan has successively experienced three stages - "work evaluation system", "faculty evaluation system" and "new teacher evaluation system" [7]. In the U.K., the teaching abilities of teachers were at first evaluated by both teachers and students. Later, Her Majesty's Inspectorate was established as the evaluation organization, emphasizing the important role of selfevaluation indicators in the evaluation of teaching abilities [8]. In the United States, the teaching abilities of teachers are evaluated mainly from three aspects - before class, during class and after class, and teachers' performance in the teaching qualification examination is the main basis for the evaluation [9]. The research on teaching abilities in China started at the end of the $19^{\text {th }}$ century and the beginning of the $20^{\text {th }}$ century. In recent years, with people attaching greater importance to education and teaching, more research has been carried out on teaching abilities. Through review of the literatures, it is found that the research mainly focuses on the teaching abilities of teachers, the cultivation of their teaching abilities, the factors affecting their teaching abilities and the evaluation indicator system for teachers' teaching abilities. There is little research on the teaching abilities of P.E. teachers and the evaluation indicators thereof [10].

Therefore, based on the teaching characteristics of physical education combined with the research results regarding the teaching abilities of P.E. teachers at home and abroad, this paper constructed a teaching ability evaluation indicator system for P.E. teachers in colleges and universities using the Defeier method, determined the weights of the indicators at each level using the expert survey method and performed empirical analysis to verify the effectiveness of the evaluation indicator system.

\section{Research object and methods}

\subsection{Research object}

This paper takes the teaching ability evaluation indicator system of P.E. teachers in colleges and universities as the research object. Teachers and experts engaged in physical education teaching and research in colleges and universities in Guizhou Province were chosen as the respondents. Through the questionnaire method, opin- 
ions and suggestions of relevant teachers and experts were collected. And at last, a teaching ability evaluation indicator system for P.E. teachers in colleges and universities was established.

\subsection{Main research methods}

1. Questionnaire method: By reference to the relevant domestic and foreign literatures and based on the research content of this paper, a questionnaire "Evaluation Indicators for Physical Education Teaching Ability of Colleges and Universities" [11] was designed. According to the needs of the research, two types of questionnaires the first round and the second round - were designed. At the same time, the "Evaluation Indicator Assignment Expert Questionnaire" [12] was also designed. Both the reliability and validity of the questionnaire meet the standards, indicating that the questionnaire is highly valid and also reliable to some extent

2. Delphi method: In this paper, the indicator system was constructed using the Delphi method. According to the characteristics of the Delphi method and the expert selection criteria, a total of 20 experts meeting the requirements were selected. Table 1 shows a list of experts. In this paper, questionnaires were distributed on site to conduct the survey, with the questionnaire recovery rate and the valid rate being both $100 \%$.

Table 1. List of experts

\begin{tabular}{|l|c|c|c|}
\hline \multicolumn{2}{|c|}{ Category } & Number of people & Proportion (\%) \\
\hline \multirow{3}{*}{ Title structure } & Professor & 6 & 30 \\
\cline { 2 - 4 } & Associate Professor & 14 & 70 \\
\hline \multirow{3}{*}{ Degree structure } & Bachelor's degree & 3 & 15 \\
\cline { 2 - 4 } & Master's degree & 12 & 60 \\
\cline { 2 - 4 } & Master's degree & 5 & 25 \\
\hline \multirow{3}{*}{ Years of teaching } & $5-10$ & 1 & 5 \\
\cline { 2 - 4 } & $11-20$ & 4 & 55 \\
\cline { 2 - 4 } & $21-30$ & 11 & 20 \\
\cline { 2 - 4 } & $31-40$ & 4 & \\
\hline
\end{tabular}

\section{Construction of the teaching ability evaluation indicator system for P.E. teachers in colleges and universities}

\subsection{Preliminary selection of evaluation indicators}

Based on previous research results, considering the status and development characteristics of physical education in colleges and universities, as well as the opinions of multiple experts, a teaching ability evaluation indicator system for P.E. teachers in colleges and universities was preliminarily established, as shown in Table 2, based on 
the principles of scientificity, comprehensiveness and feasibility. The system consists of 4 first-level indicators, 9 second-level ones and 29 third-level ones [13].

Table 2. Teaching ability evaluation indicator system for P.E. teachers in colleges and universities (first round)

\begin{tabular}{|c|c|c|}
\hline First-level indicator & $\begin{array}{l}\text { Second-level } \\
\text { indicators }\end{array}$ & Three-level indicators \\
\hline \multirow{2}{*}{$\begin{array}{l}\text { Basic Quality } \\
A_{1}\end{array}$} & $\begin{array}{l}\text { Moral Quality } \\
\mathrm{A}_{11}\end{array}$ & $\begin{array}{l}\text { Professional ethics } \mathrm{A}_{111} \\
\text { Academic ethics } \mathrm{A}_{112}\end{array}$ \\
\hline & $\begin{array}{l}\text { Physical and } \\
\text { mental qualities } \\
\mathrm{A}_{12}\end{array}$ & $\begin{array}{l}\text { Physical fitness } A_{121} \\
\text { Psychological quality } A_{122}\end{array}$ \\
\hline \multirow{3}{*}{$\begin{array}{l}\text { Teaching ability } \\
A_{2}\end{array}$} & $\begin{array}{l}\text { Instructional } \\
\text { design ability } \\
\mathrm{A}_{21}\end{array}$ & $\begin{array}{l}\text { Determining teaching goals } \mathrm{A}_{211} \\
\text { Designing teaching content } \mathrm{A}_{212} \\
\text { Designing teaching methods } \mathrm{A}_{213} \\
\text { Designing lesson plans } \mathrm{A}_{214}\end{array}$ \\
\hline & $\begin{array}{l}\text { Teaching imple- } \\
\text { mentation ability } \\
\mathrm{A}_{22}\end{array}$ & $\begin{array}{l}\text { Organizing and managing the class } \mathrm{A}_{221} \\
\text { Language expression skills } \mathrm{A}_{222} \\
\text { Demonstrating technical movements } \mathrm{A}_{223} \\
\text { Allocating teaching time } \mathrm{A}_{224}\end{array}$ \\
\hline & $\begin{array}{l}\text { Teaching evalua- } \\
\text { tion ability } \\
\mathrm{A}_{23}\end{array}$ & $\begin{array}{l}\text { Paying attention to process evaluation } \mathrm{A}_{231} \\
\text { Basing on effect evaluation } \mathrm{A}_{232} \\
\text { Accurately assessing students' performance } \mathrm{A}_{233}\end{array}$ \\
\hline \multirow{2}{*}{$\begin{array}{l}\text { Sports coaching ability } \\
A_{3}\end{array}$} & $\begin{array}{l}\text { Physical training } \\
\text { coaching ability } \\
\mathrm{A}_{31}\end{array}$ & $\begin{array}{l}\text { Selecting the content of extracurricular sports activities } \mathrm{A}_{311} \\
\text { Making plans for extracurricular sports activities } \mathrm{A}_{312} \\
\text { Organizing the implementation of extracurricular sports } \\
\text { interaction } \mathrm{A}_{313}\end{array}$ \\
\hline & $\begin{array}{l}\text { Sports organization } \\
\text { coaching ability } \\
\mathrm{A}_{32}\end{array}$ & $\begin{array}{l}\text { Organizing professional physical fitness and expand competi- } \\
\text { tion activities } \mathrm{A}_{321} \\
\text { Drawing up plans for organizing competitions } \mathrm{A}_{322} \\
\text { Drawing up competition rules } \mathrm{A}_{323} \\
\text { Dealing with problems during and after the game } \mathrm{A}_{324} \\
\end{array}$ \\
\hline \multirow{2}{*}{$\begin{array}{l}\text { Scientific research and } \\
\text { innovation ability } \\
\mathrm{A}_{4}\end{array}$} & $\begin{array}{l}\text { Research ability } \\
\mathrm{A}_{41}\end{array}$ & $\begin{array}{l}\text { Scientific research attitude } \mathrm{A}_{411} \\
\text { Research habits } \mathrm{A}_{412} \\
\text { Research workload } \mathrm{A}_{413} \\
\text { Scientific research results } \mathrm{A}_{414}\end{array}$ \\
\hline & $\begin{array}{l}\text { Creativity } \\
\mathrm{A}_{42}\end{array}$ & $\begin{array}{l}\text { Teaching method innovation } \mathrm{A}_{421} \\
\text { Innovation in teaching methods } \mathrm{A}_{422} \\
\text { Teaching content innovation } \mathrm{A}_{423}\end{array}$ \\
\hline
\end{tabular}

\subsection{Results of the first-round expert survey}

In this paper, the Likert scale was used to assign scores to the expert questionnaire, as shown in Table 3 [14]. If an expert recognizes an indicator, he will choose "very important" and "relatively important"; otherwise, it will be deemed that he does not recognize the indicator. 
Paper-Quantitative Analysis on the Evaluation Indicators of Teaching Abilities of Physical Education...

Table 3. Likert scale

\begin{tabular}{|l|c|c|c|c|c|}
\hline Indicator name & Very important & Relatively important & Average & Not so important & Very unimportant \\
\hline Score & 5 & 4 & 3 & 2 & 1 \\
\hline
\end{tabular}

According to the sorting and analysis results of the first round expert questionnaires, the overall recognition rates of the four first-level evaluation indicators of the physical education teaching abilities by experts were $100 \%$, and the coefficient of variation was 0 except for the sports coaching ability, of which the coefficient of variation was $9.8 \%(<15 \%)$. Regarding second-level indicators, the overall recognition rates were all $100 \%$ except for the sports organization coaching ability $(97.23 \%)$ and the research ability (93.43\%), and the coefficient of variation ranges between 0$15 \%$. This indicates that experts highly recognized the first-level and second-level indicators, and thus the indicators are reasonable enough to be used for evaluation of the teaching abilities of P.E. teachers and were included in the second-round expert survey.

The first-round survey results of the three-level indicators showed that except for the five indicators - "allocating teaching time" $\left(\mathrm{A}_{224}\right)$, "selecting the content of extracurricular sports activities" $\left(\mathrm{A}_{311}\right)$, "drawing up plans for organizing competitions" $\left(\mathrm{A}_{322}\right)$, "draw up competition rules" $\left(\mathrm{A}_{323}\right)$ and "research habits" $\left(\mathrm{A}_{412}\right)$, the overall recognition rates of the other indicators by experts were above $90 \%$, and the coefficients of variation were below $15 \%$. Figure 1 shows the statistical results of the experts' opinions about the five indicators, and Figure 2 shows the coefficients of variation of the five indicators.

According to the results of the first-round expert questionnaire survey and the experts' opinions, three indicators with a lower recognition rate - "allocating teaching time" $\left(\mathrm{A}_{224}\right)$, "selecting the content of extracurricular sports activities" $\left(\mathrm{A}_{311}\right)$ and "research habits" $\left(\mathrm{A}_{412}\right)$ - were deleted, and the two indicators "drawing up plans for organizing competitions" $\left(\mathrm{A}_{322}\right)$ and "drawing up competition rules" $\left(\mathrm{A}_{323}\right)$ were combined into one indicator "drawing up competition plans and rules" $\left(\mathrm{A}_{323}\right)$. The other indicators remain unchanged and were included in the second-round expert survey. 


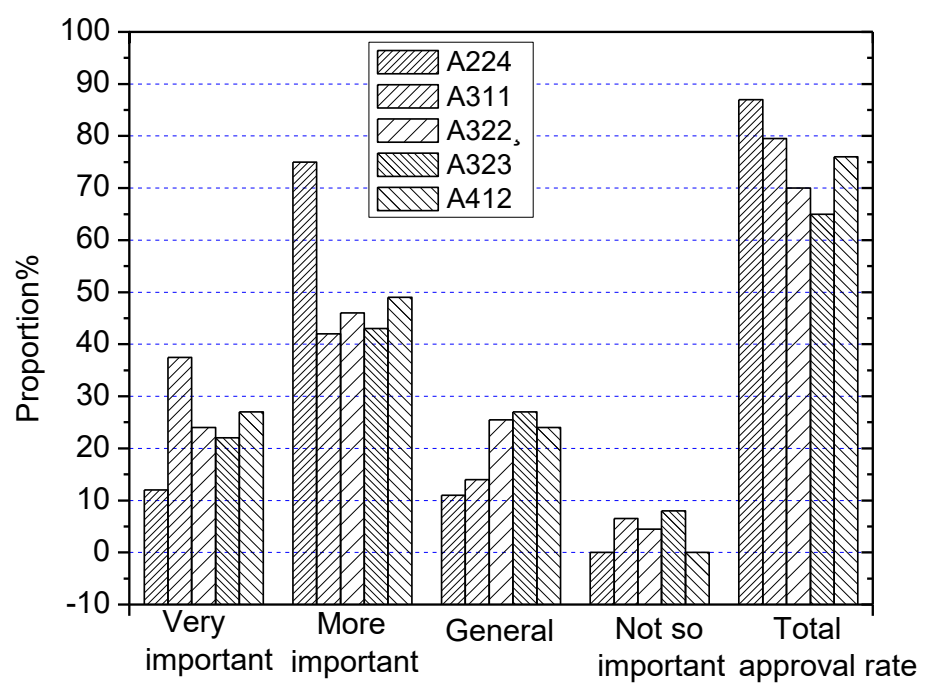

Fig. 1. Statistical results of the experts' opinions about the five indicators

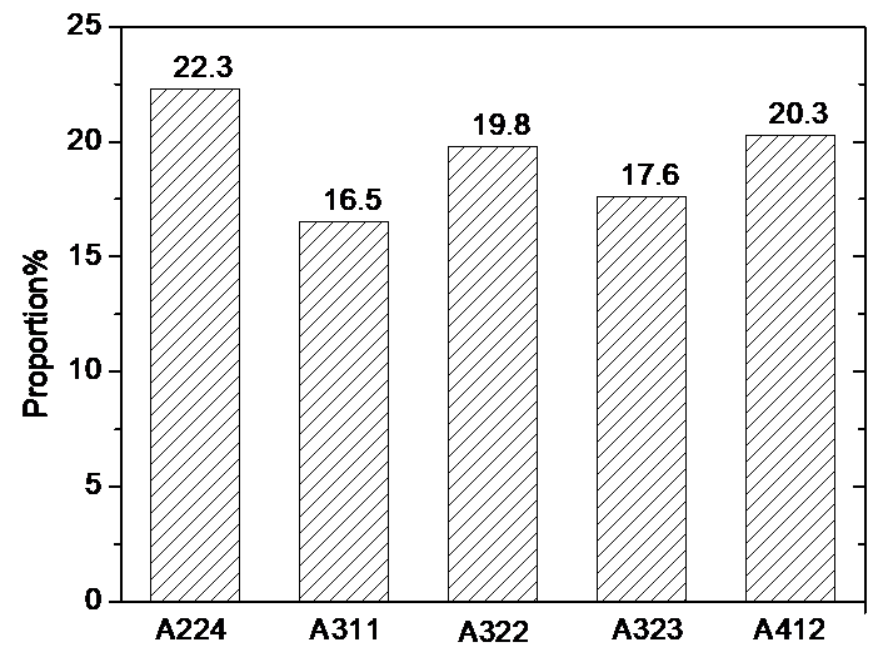

Fig. 2. Coefficients of variation of the five indicators

\subsection{Results of the second-round expert survey}

After the teaching ability evaluation indicator system was modified based on the results of the first-round survey, the second round was carried out. The statistical results of the second round showed that the overall recognition rates of the three-level indicators by experts were greater than $90 \%$, and that the coefficient of variation all less than $15 \%$, indicating that the modified indicators can be used to fully evaluate the teaching abilities of P.E. teachers and have been recognized by experts as meeting the 
needs of this research. Table 4 shows the teaching ability evaluation indicator system for P.E. teachers in colleges and universities obtained after two rounds of expert surveys. It consists of 4 first-level indicators, 9 second-level ones, and 25 third-level ones.

Table 4. Teaching ability evaluation indicator system and weights for P.E. teachers in colleges and universities

\begin{tabular}{|c|c|c|}
\hline First level indicator & Secondary indicators & Three-level indicators \\
\hline \multirow{2}{*}{$\begin{array}{l}\text { Basic Quality } \\
\mathrm{A}_{1}(0.154)\end{array}$} & $\begin{array}{l}\text { Moral Quality } \\
\mathrm{A}_{11}(0.6)\end{array}$ & $\begin{array}{l}\text { Professional ethics } \mathrm{A}_{111}(0.623) \\
\text { Academic ethics } \mathrm{A}_{112}(0.377)\end{array}$ \\
\hline & $\begin{array}{l}\text { Physical and mental quali- } \\
\text { tiesA }_{12}(0.4)\end{array}$ & $\begin{array}{l}\text { Physical fitness } \mathrm{A}_{121}(0.457) \\
\text { Psychological quality } \mathrm{A}_{122}(0.543)\end{array}$ \\
\hline \multirow{3}{*}{$\begin{array}{l}\text { Teaching ability } \\
\mathrm{A}_{2}(0.477)\end{array}$} & $\begin{array}{l}\text { Instructional design ability } \\
\mathrm{A}_{21}(0.387)\end{array}$ & $\begin{array}{l}\text { Determining teaching goals } \mathrm{A}_{211}(0.198) \\
\text { Designing teaching content } \mathrm{A}_{212}(0.159) \\
\text { Designing teaching methods } \mathrm{A}_{213}(0.476) \\
\text { Designing lesson plans } \mathrm{A}_{214}(0.167) \\
\end{array}$ \\
\hline & $\begin{array}{l}\text { Teaching implementation } \\
\text { ability } \\
\mathrm{A}_{22}(0.455) \\
\end{array}$ & $\begin{array}{l}\text { Organizing and managing the class } \mathrm{A}_{221}(0.333) \\
\text { Language expression skills } \mathrm{A}_{222}(0.346) \\
\text { Demonstrating technical movements } \mathrm{A}_{223}(0.321)\end{array}$ \\
\hline & $\begin{array}{l}\text { Teaching evaluation ability } \\
\mathrm{A}_{23}(0.158)\end{array}$ & $\begin{array}{l}\text { Paying attention to process evaluation } \mathrm{A}_{231}(0.342) \\
\text { Basing on effect evaluation } \mathrm{A}_{232}(0.190) \\
\text { Accurately assessing students' performance } \mathrm{A}_{233} \\
(0.468)\end{array}$ \\
\hline \multirow[b]{2}{*}{$\begin{array}{l}\text { Sports coaching } \\
\text { ability } \\
\mathrm{A}_{3}(0.205)\end{array}$} & $\begin{array}{l}\text { Physical training coaching } \\
\text { ability } \\
\mathrm{A}_{31}(0.158)\end{array}$ & $\begin{array}{l}\text { Making plans for extracurricular sports activities } A_{311} \\
(0.353) \\
\text { Organizing the implementation of extracurricular } \\
\text { sports interaction } \mathrm{A}_{312}(0.647)\end{array}$ \\
\hline & $\begin{array}{l}\text { Sports organization coaching } \\
\text { ability } \\
\mathrm{A}_{32}(0.158)\end{array}$ & $\begin{array}{l}\text { Organizing professional physical fitness and expand } \\
\text { competition activities } A_{321}(0.288) \\
\text { Draw up competition plans and regulations } A_{322} \\
(0.259) \\
\text { Dealing with problems during and after the game } A_{323} \\
(0.453)\end{array}$ \\
\hline \multirow{2}{*}{$\begin{array}{l}\text { Scientific research } \\
\text { and innovation } \\
\text { ability } \\
\mathrm{A}_{4}(0.164)\end{array}$} & $\begin{array}{l}\text { Research ability } \\
\mathrm{A}_{41}(0.571)\end{array}$ & $\begin{array}{l}\text { Scientific research attitude } \mathrm{A}_{411}(0.263) \\
\text { Research workload } \mathrm{A}_{412}(0.269) \\
\text { Scientific research results } \mathrm{A}_{413}(0.468) \\
\end{array}$ \\
\hline & $\begin{array}{l}\text { Creativity } \\
\mathrm{A}_{42}(0.429)\end{array}$ & $\begin{array}{l}\text { Teaching method innovation } \mathrm{A}_{421}(0.532) \\
\text { Innovation in teaching methods } \mathrm{A}_{422}(0.267) \\
\text { Teaching content innovation } \mathrm{A}_{423}(0.201)\end{array}$ \\
\hline
\end{tabular}

\subsection{Determination of the weights of the evaluation indicator system}

The weight coefficient of an indicator at a level is related to the importance of the indicator. The greater the weight coefficient is, the more important it will be, and the greater effect it will have on the evaluation result. Therefore, the weights of the evaluation indicators at all levels will have great impacts on the objectivity and accuracy of the evaluation result [15]. A scientific method should be used to properly determine the weight coefficients of indicators at all levels based on actual conditions. In this paper, the expert survey method was used to determine the weights of indicators 
[16]. Experts gave scores to the importance of each indicator according to the 5-level Likert scoring method shown in Table 3 . Then, the weight of an indicator was obtained by dividing the score of the indicator by the total score of the indicators at the same level. Table 5 shows the scores and weights of the first-level indicators. For example, the total score of the two second-level indicators under the first-level indicator "basic quality" was 326 points, and the total score of the first-level indicators "basic quality", "teaching ability", "sports coaching ability" and "scientific research and innovation ability" was 1961 points, so weight coefficient of "basic quality" was $326 / 1961=0.154$. In the same way, the weights of the second-level and third-level indicators were obtained, specifically shown in Table 4.

Table 5. Scores and weights of first-level indicators

\begin{tabular}{|l|c|c|c|}
\hline \multicolumn{1}{|c|}{ Primary indicator name } & $\begin{array}{c}\text { Total score of each } \\
\text { indicator }\end{array}$ & \multirow{2}{*}{ Total score } & Weight coefficient \\
\hline Basic quality A1 & 302 & & 0.154 \\
\hline Teaching ability A2 & 935 & \multirow{2}{*}{1961} & 0.477 \\
\cline { 1 - 2 } \cline { 1 - 1 } Sports coaching ability A3 & 402 & & 0.205 \\
\cline { 1 - 2 } Scientific research and innovation ability A4 & 322 & & 0.164 \\
\hline
\end{tabular}

\subsection{Quantitative evaluation on the teaching abilities of P.E. teachers in colleges and universities}

In order to quantitatively evaluate the teaching abilities of P.E. teachers in colleges and universities, the evaluation criteria were first quantified, as shown in Table 6. Based on the scores, there were four ratings - excellent, good, fair and poor [17]. In addition, the three-level indicators determined in the teaching ability evaluation indicator system for P.E. teachers in colleges and universities were used as the main basis for the evaluation on teachers' abilities. In this way, the standard scale for evaluation of P.E. teaching abilities in colleges and universities was developed. As shown in Table 7, the evaluator only needs to tick the corresponding box of the teaching ability indicator. Each indicator has a full score of 100. A teacher's final evaluation score is obtained after the indicator scores are converted using the assigned weight coefficients [18].

Table 6. Teaching ability ratings

\begin{tabular}{|c|c|c|c|c|}
\hline Evaluation grade & Excellent & Good & Fair & Poor \\
\hline Corresponding score & $90-100$ & $80-89$ & $79-60$ & $<60$ \\
\hline
\end{tabular}


Paper-Quantitative Analysis on the Evaluation Indicators of Teaching Abilities of Physical Education..

Table 7. Standard scale for teaching ability evaluation of P.E. teachers in colleges and universities

\begin{tabular}{|c|c|c|c|c|c|c|c|}
\hline \multicolumn{2}{|c|}{ Quantitative evaluation content } & \multirow{2}{*}{$\begin{array}{l}\text { Weight } \\
\text { coefficient }\end{array}$} & \multicolumn{4}{|c|}{ Rating } & \multirow{2}{*}{$\begin{array}{l}\text { Evaluation } \\
\text { score }\end{array}$} \\
\hline $\begin{array}{l}\text { First level } \\
\text { indicator }\end{array}$ & Three-level indicators & & $\begin{array}{c}\text { Excellent } \\
100\end{array}$ & $\begin{array}{c}\text { Good } \\
80\end{array}$ & $\begin{array}{c}\text { Fair } \\
70\end{array}$ & $\begin{array}{c}\text { Poor } \\
60\end{array}$ & \\
\hline \multirow{4}{*}{$\begin{array}{l}\text { Basic quality } \\
\mathrm{A}_{1} \\
(15.4)\end{array}$} & Professional ethics $\mathrm{A}_{111}$ & 6.23 & & & & & \\
\hline & Academic ethics $\mathrm{A}_{112}$ & 3.77 & & & & & \\
\hline & Physical fitness $\mathrm{A}_{121}$ & 4.57 & & & & & \\
\hline & Psychological quality $\mathrm{A}_{122}$ & 5.43 & & & & & \\
\hline \multirow{10}{*}{$\begin{array}{l}\text { Teaching ability } \\
\mathrm{A}_{2} \\
(47.7)\end{array}$} & Determining teaching goals $\mathrm{A}_{211}$ & 1.98 & & & & & \\
\hline & Designing teaching content $\mathrm{A}_{212}$ & 1.59 & & & & & \\
\hline & Designing teaching methods $\mathrm{A}_{213}$ & 4.76 & & & & & \\
\hline & The designing lesson plans $\mathrm{A}_{214}$ & 1,67 & & & & & \\
\hline & $\begin{array}{l}\text { Organizing and managing the class } \\
\mathrm{A}_{221}\end{array}$ & 3.33 & & & & & \\
\hline & Language expression skills $\mathrm{A}_{222}$ & 3.46 & & & & & \\
\hline & $\begin{array}{l}\text { Demonstrating technical movements } \\
\mathrm{A}_{223}\end{array}$ & 3.21 & & & & & \\
\hline & $\begin{array}{l}\text { Paying attention to process evalua- } \\
\text { tion } A_{231}\end{array}$ & 3.42 & & & & & \\
\hline & Basing on effect evaluation $\mathrm{A}_{232}$ & 1.90 & & & & & \\
\hline & $\begin{array}{l}\text { Accurately assessing students' } \\
\text { performance } \mathrm{A}_{233}\end{array}$ & 4.68 & & & & & \\
\hline \multirow{5}{*}{$\begin{array}{l}\text { Sports coaching } \\
\text { ability } \\
A_{3} \\
(20.5)\end{array}$} & $\begin{array}{l}\text { Making plans for extracurricular } \\
\text { sports activities } A_{311}\end{array}$ & 3.53 & & & & & \\
\hline & $\begin{array}{l}\text { Organizing the implementation of } \\
\text { extracurricular sports interaction } \\
A_{312}\end{array}$ & 6.47 & & & & & \\
\hline & $\begin{array}{l}\text { Organizing professional physical } \\
\text { fitness and expand competition } \\
\text { activities } A_{321}\end{array}$ & 2.88 & & & & & \\
\hline & $\begin{array}{l}\text { Draw up competition plans and } \\
\text { regulations } \mathrm{A}_{322}\end{array}$ & 2.59 & & & & & \\
\hline & $\begin{array}{l}\text { Dealing with problems during and } \\
\text { after the game } A_{323}\end{array}$ & 4.53 & & & & & \\
\hline \multirow{6}{*}{$\begin{array}{l}\text { Scientific re- } \\
\text { search and } \\
\text { innovation } \\
\text { ability } \\
\mathrm{A}_{4} \\
(16.4)\end{array}$} & Scientific research attitude $\mathrm{A}_{411}$ & 2.63 & & & & & \\
\hline & Research workload $\mathrm{A}_{412}$ & 2.69 & & & & & \\
\hline & Scientific research results $\mathrm{A}_{413}$ & 4.68 & & & & & \\
\hline & Teaching method innovation $\mathrm{A}_{421}$ & 5.32 & & & & & \\
\hline & Innovation in teaching methods $\mathrm{A}_{422}$ & 2.67 & & & & & \\
\hline & Teaching content innovation $\mathrm{A}_{423}$ & 2.01 & & & & & \\
\hline
\end{tabular}




\section{Application of the teaching ability evaluation indicators in sports majors in colleges and universities}

In order to verify the practicality of the standard scale for the teaching ability evaluation of P.E. teachers in colleges and universities, in this paper, a P.E. teacher of the sports major in a college in Guizhou Province was taken as the subject. In the experiment, 25 students randomly selected from the classes he teaches used this standard scale to evaluate his teaching abilities. The evaluation results are shown in Figure 3. The percentage of the excellent rating was $72 \%$, and the average score of the teacher given by his students was 92.3 , which was excellent. At the same time, a total of 5 school leaders and experts were invited to evaluate the teacher's teaching abilities. After attending his teaching classes and doing interviews with him, they gave the evaluation results of the teaching abilities of this teacher, as shown in Figure 4. It can be seen that 3 persons found this teacher excellent, one found him good and the other one found him fair. The average score given by school leaders and experts was 90.36 , falling within the excellent range, which was consistent with the evaluation result given by the students. This indicates that the proposed standard scale for teaching ability evaluation of P.E. teachers in colleges and universities is operable and practical and can evaluate the teaching abilities of teachers objectively and fairly. At the same time, it can also help identify the deficiencies in teachers' teaching abilities based on the scores of different indicators, allowing the teachers to understand what to improve in teaching.

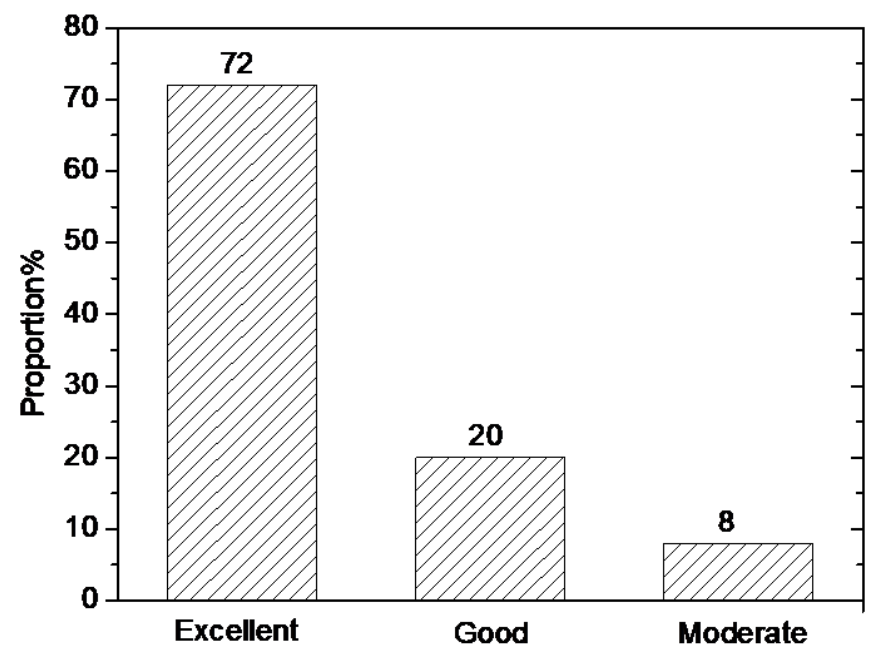

Fig. 3. Evaluation results given by students 


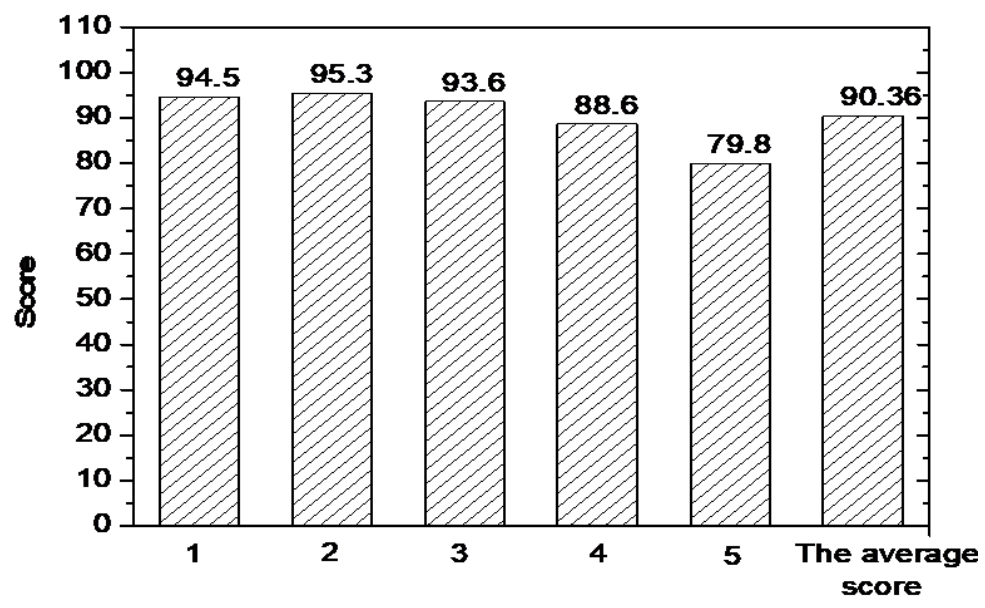

Fig. 4. Evaluation results given by school leaders and experts

\section{Conclusions}

Scientific and objective evaluation of teachers' teaching abilities allows teachers to correct their problems and make up for their deficiencies, which is very important to improving teachers' teaching quality. This paper studied the quantitative analysis on the teaching ability evaluation indicators of P.E. teachers in colleges and universities, and the specific conclusions are as follows:

1. With the aid of the Delphi method, through two rounds of expert questionnaire surveys, a teaching ability evaluation indicator system for P.E. teachers in colleges and universities was finally established, consisting of 4 first-level indicators, 9 second-level ones and 25 third-level ones.

2. The weights of the indicators at all levels in the evaluation indicator system were determined by the expert survey method, and the standard scale for teaching ability evaluation was developed.

3. The proposed standard scale for teaching ability evaluation was used to evaluate the teaching abilities of a P.E. teacher in a college in Guizhou Province. The evaluation results given by the students and the teachers were both "excellent", proving the practicality of the evaluation standard scale.

\section{References}

[1] Faulkner, G., Reeves, C. (2000). Primary school student teachers' physical self-perceptions and attitudes toward teaching physical education. Journal of Teaching in Physical Education, 19(3): 31. https://doi.org/10.1123/jtpe.19.3.311

[2] Hauer, M.P., Hofmann, X.C., Krafft, T.D., Zweig, K.A. (2020). Quantitative analysis of automatic performance evaluation systems based on the h-index. Scientometrics, 123(2): 735-751. https://doi.org/10.1007/s11192-020-03407-7 
Paper - Quantitative Analysis on the Evaluation Indicators of Teaching Abilities of Physical Education...

[3] Boysen, G.A. (2015). Uses and misuses of student evaluations of teaching: the interpretation of differences in teaching evaluation means irrespective of statistical information. Teaching of Psychology, 42(2): 109-118. https://doi.org/10.1177/00986 $\underline{28315569922}$

[4] Michalsky, T. (2012). Shaping self-regulation in science teachers' professional growth: Inquiry skills. Science Education, 96(6): 1106-1133. https://doi.org/10.1002/sce.21029

[5] Wu, Y. (2020). Study on evaluation of marine physical education curriculum system in the context of marine power. Journal of Coastal Research, 115(s1): 259-261. https://doi.org/ $\underline{10.2112 / j \mathrm{j}-\mathrm{si} 115-082.1}$

[6] Oliver, J.N. (2011). An analysis of the various factors associated with the assessment of teaching ability in physical education. British Journal of Educational Psychology, 26(1): 66-77. https://doi.org/10.1111/j.2044-8279.1956.tb01358.x

[7] Biggs, J., Chopra, P. (1979). Pupil evaluation of teachers. Australian Journal of Education, 23(1): 45-57. https://doi.org/10.1177/000494417902300105

[8] Wang, Y. (2019). The automatic evaluation model of physical education teaching based on two screening algorithms. Journal of Intelligent and Fuzzy Systems, 37(5): 5945-5953. https://doi.org/10.3233/jifs-179176

[9] Metzler, M.W. (1986). Using systematic analysis to promote teaching skills in physical education: Theme. Journal of Teacher Education, 37(4): 29 33. https://doi.org/10.1177/ $\underline{002248718603700406}$

[10] Imwold, C.H., Rider, R.A., Johnson, D.J. (1982). The use of evaluation in public school physical education programs. Journal of Teaching in Physical Education, 2(1): 13-18. https://doi.org/10.1123/itpe.2.1.13

[11] Leyton Román, M., Lobato Muñoz, S., Jiménez Castuera, R. (2019). The importance of assigning responsibility during evaluation in order to increase student satisfaction from physical education classes: A structural equation model. PloS One, 14(9): e0209398. https://doi.org/10.1371/journal.pone.0209398

[12] Bao, L., Yu, P. (2021). Evaluation method of online and offline hybrid teaching quality of physical education based on mobile edge computing. Mobile Networks and Applications. https://doi.org/10.1007/s11036-021-01774-w

[13] Mcnaught, C., Grant, H., Fritze, P., BaRton, J., Mctigue, P., Prosser, R. (1995). The effectiveness of computer-assisted learning in the teaching of quantitative volumetric analysis skills in a first-year university course. Journal of Chemical Education, 72(11): 1003-1007. https://doi.org/10.1021/ed072p1003

[14] Chen, Z. (2021). Using big data fuzzy k-means clustering and information fusion algorithm in English teaching ability evaluation. Complexity. https://doi.org/10.1155/ $\underline{2021 / 5554444}$

[15] Leung, J., Ross, M. (2012). Quantitative evaluation of public health teaching in a multi-site medical school. Medical Teacher, 34(7): 598-598. https://doi.org/10.3109/0142159x. $\underline{2012.675215}$

[16] Bezeau, D., Turcotte, S., Beaudoin, S., Grenier, J. (2020). Health education assessment practices used by physical education and health teachers in a collaborative action research. Physical Education and Sport Pedagogy, 25(4): 379-393. https://doi.org/10.1080/ 17408989.2020 .1725457

[17] Start, K.B. (1968). Rater-ratee personality in the assessment of teaching ability. British Journal of Educational Psychology, 38(1): 14-20. https://doi.org/10.1111/j.2044-8279. $\underline{1968 . t b 01976 . x}$ 
Paper-Quantitative Analysis on the Evaluation Indicators of Teaching Abilities of Physical Education..

[18] Boud, D., Falchikov, N. (1989). Quantitative studies of student self-assessment in higher education: a critical analysis of findings. Higher Education, 18(5): 529-549. https://doi.org $\underline{/ 10.1007 / \mathrm{bf} 00138746}$

\section{Author}

Xinjun Luo graduated from the Physical Education Department of Guizhou Normal University. Now, he works in the Physical Education Department of Guizhou business college, His main research direction is physical education and training.

Article submitted 2021-06-21. Resubmitted 2021-07-29. Final acceptance 2021-07-29. Final version published as submitted by the authors. 